\title{
ENDOCRINOLOGY IN PREGNANCY
}

\section{Influence of maternal vitamin D status on obstetric outcomes and the fetal skeleton}

\author{
Rebecca J Moon ${ }^{1,2}$, Nicholas C Harvey ${ }^{1,3, *}$ and Cyrus Cooper ${ }^{1,3,4, *}$ \\ ${ }^{1}$ MRC Lifecourse Epidemiology Unit, Southampton General Hospital, University of Southampton, \\ Tremona Road, Southampton SO16 6YD, UK, ${ }^{2}$ Paediatric Endocrinology, University Hospitals Southampton NHS \\ Foundation Trust, Tremona Road, Southampton SO16 6YD, UK, ${ }^{3}$ NIHR Southampton Biomedical Research Centre, \\ University of Southampton and University Hospital Southampton NHS Foundation Trust, Tremona Road, \\ Southampton SO16 6YD, UK and ${ }^{4}$ NIHR Musculoskeletal Biomedical Research Unit, University of Oxford, \\ Oxford OX3 7LD, UK \\ *(N C Harvey and C Cooper are joint senior author)
}

\author{
Correspondence \\ should be addressed \\ to C Cooper \\ Email \\ cc@mrc.soton.ac.uk
}

\section{Abstract}

Vitamin D status has been increasingly associated with wide-ranging clinical outcomes. There is now a wealth of observational studies reporting on its associations with obstetric complications, including pre-eclampsia, gestational diabetes and the mode and timing of delivery. The findings are inconsistent, and currently there is a lack of data from high-quality intervention studies to confirm a causal role for vitamin $D$ in these outcomes. This is similarly true with regards to fetal development, including measures of fetal size and skeletal mineralisation. Overall, there is an indication of possible benefits of vitamin $D$ supplementation during pregnancy for offspring birthweight, calcium concentrations and bone mass as well as for reduced maternal pre-eclampsia. However, for none of these outcomes is the current evidence base conclusive, and the available data justify the instatement of high-quality randomised placebo controlled trials in a range of populations and health care settings to establish the potential efficacy and safety of vitamin D supplementation to improve particular outcomes.

\section{Introduction}

The classical role of vitamin $\mathrm{D}$ is in calcium and phosphate homoeostasis: it is without doubt that severe vitamin D deficiency (VDD) can result in rickets, osteomalacia and hypocalcaemia. However, there has been increasing evidence to suggest that VDD is associated with wideranging clinical outcomes, including pregnancy complications and adverse fetal development. As a result, a number of national guidelines recommend vitamin $\mathrm{D}$

Invited Author's profile

Cyrus Cooper is Professor of Rheumatology and Director of the MRC Lifecourse Epidemiology Unit, Vice Dean of the Faculty of Medicine at the University of Southampton, and Professor of Musculoskeletal Science at the University of Oxford. He leads an internationally competitive programme of research in the epidemiology of musculoskeletal disorders, most notably osteoporosis. He is Chairman of the Committee of Scientific Advisors, International Osteoporosis Foundation, Chair of the Arthritis Research UK Clinical Studies Initiative, Chair of the BHF Project Grants Committee, an NIHR Senior Investigator, and Associate Editor of Osteoporosis International. He has published extensively on osteoporosis and rheumatic disorders and has pioneered clinical studies on the developmental origins of peak bone mass.

(C) 2015 European Society of Endocrinology Printed in Great Britain
Published by Bioscientifica Ltd. 
supplementation during pregnancy $(1,2,3)$, although this is not currently supported by the World Health Organisation (4). In the present review, we consider the evidence basis for antenatal vitamin D supplementation to prevent obstetric complications and the influence of vitamin D on fetal growth and skeletal development.

\section{Literature search}

The present review is based on literature identified through our recently published systematic review of vitamin D in pregnancy (in relation to both maternal and offspring outcomes), in which published and grey literature were comprehensively searched for maternal and offspring health outcomes across a wide range of databases from their inception until 2012 (5). A full systematic update was outside the scope of the present review, but we aimed to identify important additional studies using the US National Library of Medicine National Institutes of Health (www.pubmed.com) with the search terms 'vitamin D' AND 'pregnancy' up to August 2014.

\section{Vitamin D physiology and epidemiology in pregnancy}

Vitamin D can be derived from the diet as either ergocalciferol (vitamin $\mathrm{D}_{2}$ ) from plant sources or as cholecalciferol (vitamin $\mathrm{D}_{3}$ ) from animal sources. However, the majority is formed endogenously within the skin from the action of ultraviolet B (UVB; $290-315 \mathrm{~nm}$ wavelength) to convert 7-dehydrocholesterol to previtamin $\mathrm{D}_{3}$. Hydroxylation within the liver produces 25-hydroxyvitamin $\mathrm{D}(25(\mathrm{OH}) \mathrm{D})$. This is the main circulating form of vitamin $\mathrm{D}$, and it is found either bound to vitamin D binding protein (VDP), bound to albumin or in the free form. $25(\mathrm{OH}) \mathrm{D}$ acts as a reservoir for conversion to 1,25 -dihydroxyvitamin $\mathrm{D}\left(1,25(\mathrm{OH})_{2} \mathrm{D}\right)$, primarily in the renal proximal tubular cells, but also within bone, the parathyroid gland and placenta. Although $1,25(\mathrm{OH})_{2} \mathrm{D}$ is the active metabolite, its production is regulated in response to serum calcium and its half life is short, at $4-6 \mathrm{~h}$. Conversely, hepatic 25-hydroxylation is not physiologically regulated, and $25(\mathrm{OH}) \mathrm{D}$ has a half-life of $\sim 2-3$ weeks (6). Therefore, serum $25(\mathrm{OH}) \mathrm{D}$ is currently considered the best marker of vitamin D status (7).

The primary function of $1,25(\mathrm{OH})_{2} \mathrm{D}$ is calcium and phosphate homoeostasis, which occurs in conjunction with parathyroid hormone (PTH). Thus, low serum ionised $\mathrm{Ca}^{2+}$ stimulates PTH release, which simultaneously increases renal calcium reabsorption in the distal tubule of the kidney, decreases proximal tubule phosphate reabsorption, and increases $1,25(\mathrm{OH})_{2} \mathrm{D}$ synthesis. The main action of $1,25(\mathrm{OH})_{2} \mathrm{D}$ is to increase the uptake of dietary calcium through the intestinal enterocytes, but it also enables the PTH-induced mobilisation of calcium and phosphate from bone mineral (8).

During pregnancy, alterations to calcium and phosphate metabolism occur to allow the accretion of calcium within the fetal skeleton, particularly during the final trimester (9). This occurs through increased maternal intestinal calcium absorption $(10,11)$ and the mobilisation of calcium within the maternal skeletal (12) but without alteration to the maternal serum ionised calcium concentration. Maternal calcitropic hormones, including $1,25(\mathrm{OH})_{2} \mathrm{D}$, likely play an important role in these adaptations, seeing as total $1,25(\mathrm{OH})_{2} \mathrm{D}$ increases during the second and third trimesters $(10,13)$. This could, however, also reflect the increase in VDP from early to late pregnancy $(11,14)$. The increase in $1,25(\mathrm{OH})_{2} \mathrm{D}$ appears to be independent of $\mathrm{PTH}$, which remains within the normal adult range throughout pregnancy (9). However, PTH-related protein (PTHrP) is elevated in the maternal circulation beginning in early pregnancy and might contribute to the rise in $1,25(\mathrm{OH})_{2} \mathrm{D}$ (13). The effect of pregnancy on $25(\mathrm{OH}) \mathrm{D}$ is less well understood: Zhang et al. (14) observed a reduction in $25(\mathrm{OH}) \mathrm{D}$ in late pregnancy as compared to early pregnancy, but this might have been a reflection of seasonal variation, seeing as all of the subjects were recruited in summer months. In contrast, Ritchie et al. (11) reported no significant differences in $25(\mathrm{OH}) \mathrm{D}$ measured in 14 women before pregnancy, during each trimester and during lactation. Nonetheless, biochemically low levels of $25(\mathrm{OH}) \mathrm{D}$ are highly prevalent: in a cohort of predominantly Caucasian women in the UK, 31\% had a serum $25(\mathrm{OH}) \mathrm{D}$ of $<50 \mathrm{nmol} / \mathrm{l}$, which is widely considered to be insufficient, and $18 \%$ had $<25 \mathrm{nmol} / \mathrm{l}$, which is often considered deficient (15). However, in an ethnically more diverse UK population, $36 \%$ of women had a $25(\mathrm{OH}) \mathrm{D}$ of $<25 \mathrm{nmol} / \mathrm{l}$ at pregnancy booking (16). Indeed, dark skin pigmentation and extensive skin covering (e.g. for religious or cultural reasons) are the strongest risk factors for VDD. Obesity is also associated with biochemically low $25(\mathrm{OH}) \mathrm{D}$ levels, whereas in pregnancy, the use of vitamin D supplements may prevent deficiency (15). Maternal $25(\mathrm{OH}) \mathrm{D}$ in pregnancy is an important consideration, because the fetus is entirely dependent on the mother for $25(\mathrm{OH}) \mathrm{D}$. 25(OH)D readily crosses the placenta, and maternal and umbilical cord venous blood $25(\mathrm{OH}) \mathrm{D}$ are moderately to highly correlated, with umbilical cord 
concentrations typically being lower than those of the maternal blood, although the reported correlation coefficient does vary markedly between studies $(r=0.44-0.89(17,18,19,20))$. Randomised controlled trials have clearly demonstrated that vitamin D supplementation during pregnancy can increase umbilical cord venous and neonatal serum $25(\mathrm{OH}) \mathrm{D}$ as compared to a placebo $(21,22,23,24,25,26,27,28)$.

\section{Obstetric complications}

\section{Observational studies}

Numerous observational studies have reported associations between either vitamin $\mathrm{D}$ intake in pregnancy or serum measurement of $25(\mathrm{OH}) \mathrm{D}$ and pregnancy complications, including gestational hypertension (GHT) and pre-eclampsia (PET), gestational diabetes (GDM), timing of delivery and mode of delivery. The interpretation and comparison of these studies is limited by the timing of $25(\mathrm{OH}) \mathrm{D}$ measurements, which range from first trimester to delivery, the definitions used for both VDD and the outcome, the covariates that are included and the study design (e.g. prospective cohort or case-control).

\section{Gestational hypertension and pre-eclampsia}

Although the aetiology of PET is poorly understood and likely multifactorial, there is some evidence that maternal calcium status might be important and that calcium supplementation can reduce PET risk, particularly in women with low calcium intake (29). Thus, exploring a role for calcitropic hormones, including vitamin $\mathrm{D}$, is a sensible approach. Several case-control and prospective cohort studies have demonstrated that women who developed PET had lower serum $25(\mathrm{OH}) \mathrm{D}$ as compared to controls in early $(30,31,32)$, mid- $(33,34)$ or late $(30,35,36)$ pregnancy and that VDD increased the risk of PET $(30,35$, $37)$. One case-control study suggested that women with serum $25(\mathrm{OH}) \mathrm{D}$ of $<37.5 \mathrm{nmol} / 1$ at $<22$ weeks gestation had a fivefold higher risk of PET than did women with a $25(\mathrm{OH}) \mathrm{D}$ of $>37.5 \mathrm{nmol} / \mathrm{l}$, independent of ethnicity, season, gestational age at sampling, pre-pregnancy BMI and educational achievement (30). Similarly, in a cohort of 23425 pregnant women in Norway, lower vitamin D intake that was estimated from a food frequency questionnaire at 22 weeks gestation was associated with a significantly increased risk of PET (38). The lower vitamin D intake in women who developed PET was mostly the result of a difference in vitamin D obtained from supplements, which suggests that supplementation might prevent PET. However, these findings are not supported by all studies $(32,39,40,41$, $42,43,44,45,46)$. Indeed, in a prospective cohort of 1591 women, for each additional $25 \mathrm{nmol} / 1$ increment in $25(\mathrm{OH}) \mathrm{D}$ in early pregnancy, the risk of gestational hypertension (GHT) (without PET) increased by 30\%, but no effect on PET risk was observed (43), which highlights possible detrimental effects of higher vitamin D status.

In recent years, there have been several published meta-analyses of the relationship between maternal vitamin $\mathrm{D}$ status and PET risk, as shown in Table 1 $(5,47,48,49,50,51)$. As with the observational studies, the conclusions of these meta-analyses are inconsistent. In our own meta-analysis, we found no significant reduction in the risk of PET with higher vitamin D status (Fig. 1) (5). In contrast, Aghajafari et al. (49) found that the increased risk of PET in VDD was only observed in studies in which blood sampling occurred after 16 weeks gestation and when VDD was defined as 25(OH)D of $<75 \mathrm{nmol} / \mathrm{l}$ and not $<50 \mathrm{nmol} / 1$. However, Tabesh et al. (50), who included a larger number of studies that defined VDD as $<50 \mathrm{nmol} / \mathrm{l}$, demonstrated an increased risk of PET, which was not found when deficiency was defined as $<38 \mathrm{nmol} / \mathrm{l}$. Importantly, the total number of women included in these meta-analyses varied from 610 to 2485 (excluding those based on intake only and the most recent meta-analyses, which included novel data (47)). However, between January 2013 and July 2014, at least a further 14 case-control or prospective cohort studies that measured serum $25(\mathrm{OH}) \mathrm{D}$ and assessed PET risk have been published $(32,36,37,44,45,46,47,52,53,54,55,56,57,58,59)$. These newer studies include data for an additional 21000 women, considerably more than were included in the published meta-analyses.

\section{Gestational diabetes}

Similarly to PET, conflicting findings have been reported for $25(\mathrm{OH}) \mathrm{D}$ status in case-control and prospective cohort studies of GDM risk: both lower $(52,60,61,62,63,64,65)$ and similar serum $25(\mathrm{OH}) \mathrm{D}(66,67)$ during pregnancy in women with and without GDM have been reported. One study of women who were referred for GDM screening did not find a difference in the prevalence of GDM in women with $25(\mathrm{OH}) \mathrm{D}$ of more than and $<50 \mathrm{nmol} / \mathrm{l}$, but the women with $25(\mathrm{OH}) \mathrm{D}$ of $<50 \mathrm{nmol} / 1$ did have higher fasting blood glucose, HBA1c and insulin resistance. However these women also had higher BMI, lower physical activity and were less likely to be Caucasian, which might have confounded the findings (68). Three separate 
Table 1 Meta-analyses of maternal vitamin D status (intake and serum 25-hydroxyvitamin D level) and risk of pre-eclampsia.

\begin{tabular}{|c|c|c|c|c|c|c|}
\hline \multirow[b]{2}{*}{ Author } & \multirow[b]{2}{*}{$\begin{array}{l}\text { Publication } \\
\text { cut-off }\end{array}$} & \multirow{2}{*}{$\begin{array}{l}\text { Number of } \\
\text { studies } \\
\text { included }\end{array}$} & \multirow{2}{*}{$\begin{array}{l}\text { Number of } \\
\text { women } \\
\text { included }\end{array}$} & \multirow[b]{2}{*}{ Comparison } & \multicolumn{2}{|c|}{$\begin{array}{l}\text { Risk of pre-eclampsia with } \\
\text { low vitamin D status }\end{array}$} \\
\hline & & & & & $\begin{array}{l}\text { Direction } \\
\text { of effect }\end{array}$ & $\begin{array}{l}\text { Reported odds } \\
\text { ratio }(95 \% \mathrm{Cl})\end{array}$ \\
\hline \multicolumn{7}{|l|}{ Vitamin D intake } \\
\hline Thorne-Lyman (2012) (48) & June 2011 & 2 & 25141 & $\begin{array}{l}\text { Highest vs lowest category } \\
\text { of vitamin D intake }\end{array}$ & $\leftrightarrow$ & $0.95(0.86,1.06)$ \\
\hline Hypponen (2013) (47) & $\begin{array}{l}\text { March } 2013+ \\
\text { inclusion of } \\
\text { novel data }\end{array}$ & 2 & 77165 & $\begin{array}{l}\text { Self-supplementation vs } \\
\text { unsupplemented }\end{array}$ & $\uparrow$ & $1.23(1.15,1.33)$ \\
\hline \multicolumn{7}{|l|}{ Serum $25(\mathrm{OH}) \mathrm{D}$} \\
\hline \multirow[t]{4}{*}{ Aghajafari (2013) (49) } & August 2012 & 2 & 697 & $\begin{array}{l}\text { Serum } 25(\mathrm{OH}) \mathrm{D} \geq 50 \mathrm{nmol} / \mathrm{l} \\
\quad \text { vs }<50 \mathrm{nmol} / \mathrm{l}\end{array}$ & $\leftrightarrow$ & $1.27(0.67,2.42)$ \\
\hline & & 5 & 1165 & $\begin{array}{l}\text { Serum } 25(\mathrm{OH}) \mathrm{D} \geq 75 \mathrm{nmol} / \mathrm{l} \\
\quad \text { vs }<75 \mathrm{nmol} / \mathrm{l}\end{array}$ & $\uparrow$ & $2.11(1.36,3.27)$ \\
\hline & & 7 & 1862 & $\begin{array}{l}\text { Higher serum 25(OH)D as } \\
\text { defined by each study } \\
\text { vs lower serum } 25(\mathrm{OH}) \mathrm{D}\end{array}$ & $\uparrow$ & $1.79(1.25,2.58)$ \\
\hline & & 7 & 1862 & $\begin{array}{l}\text { Higher serum } 25(\mathrm{OH}) \mathrm{D} \text { as } \\
\text { defined by each study } \\
\text { vs lower serum } 25(\mathrm{OH}) \mathrm{D} \text {, } \\
\text { adjusted for 'critical } \\
\text { confounders' }\end{array}$ & $\leftrightarrow$ & $1.51(0.89,2.57)$ \\
\hline Hypponen (2013) (47) & $\begin{array}{l}\text { March } 2013+ \\
\text { inclusion of } \\
\text { novel data }\end{array}$ & 6 & 6864 & $\begin{array}{l}\text { Higher serum } 25(\mathrm{OH}) \mathrm{D} \text { as } \\
\text { defined by each study vs } \\
\text { lower serum } 25(\mathrm{OH}) \mathrm{D}\end{array}$ & $\uparrow$ & $1.92(1.12,3.33)$ \\
\hline \multirow[t]{3}{*}{ Tabesh (2013) (50) } & $\begin{array}{l}\text { December } \\
2012\end{array}$ & 4 & 931 & $\begin{array}{l}\text { Serum } 25(\mathrm{OH}) \mathrm{D} \geq 38 \mathrm{nmol} / \mathrm{l} \\
\quad \text { vs }<38 \mathrm{nmol} / \mathrm{l}\end{array}$ & $\leftrightarrow$ & $\begin{array}{l}\text { Actual odds } \\
\text { ratios not }\end{array}$ \\
\hline & & 5 & 1775 & $\begin{array}{l}\text { Serum } 25(\mathrm{OH}) \mathrm{D} \geq 50 \mathrm{nmol} / \mathrm{l} \\
\quad \text { vs }<50 \mathrm{nmol} / \mathrm{l}\end{array}$ & $\uparrow$ & reported \\
\hline & & 8 & 2485 & $\begin{array}{l}\text { Higher serum } 25(\mathrm{OH}) \mathrm{D} \text { as } \\
\text { defined by each study vs } \\
\text { lower serum 25(OH)D }\end{array}$ & $\uparrow$ & \\
\hline \multirow[t]{2}{*}{ Wei (2013) (51) } & October 2012 & 6 & 610 & $\begin{array}{l}\text { Serum } 25(\mathrm{OH}) \mathrm{D} \geq 50 \mathrm{nmol} / \mathrm{l} \\
\quad \text { vs }<50 \mathrm{nmol} / \mathrm{l}\end{array}$ & $\uparrow$ & $2.09(1.50,2.90)$ \\
\hline & & 5 & 802 & $\begin{array}{l}\text { Serum } 25(\mathrm{OH}) \mathrm{D} \geq 75 \mathrm{nmol} / \mathrm{l} \\
\quad \text { vs }<75 \mathrm{nmol} / \mathrm{l}\end{array}$ & $\uparrow$ & $1.78(1.23,2.56)$ \\
\hline Harvey (2014) (5) & June 2012 & 4 & 628 & $\begin{array}{l}\text { Each } 25 \mathrm{nmol} / \mathrm{l} \text { increase in } \\
\text { serum } 25(\mathrm{OH}) \mathrm{D}\end{array}$ & $\leftrightarrow$ & $0.78(0.59,1.05)$ \\
\hline
\end{tabular}

meta-analyses of published studies all concluded that women with GDM had significantly lower mean 25(OH)D than normoglycaemic women did $(49,51,69)$, with the mean difference in $25(\mathrm{OH}) \mathrm{D}$ ranging from 3.9 to $7.4 \mathrm{nmol} / \mathrm{l}$. Furthermore, these meta-analyses suggested that the risk of GDM was increased by $40-60 \%$ in women with VDD $(49,51,69)$, as shown in Fig. 2 (49). However, as was the case with the studies that assessed PET risk, there is now substantially more data available than there was for these meta-analyses $(44,52,62,63,64,65,67,70)$. Although many of the smaller studies would have supported the previous conclusions, a large prospective cohort of women in Australia, including 5109 women, of whom 7.4\% developed GDM, first trimester VDD (defined either as $<25 \mathrm{nmol} / \mathrm{l}$ or $<37.5 \mathrm{nmol} / \mathrm{l}$ ) was not associated with an increased risk of GDM as compared to $50-75 \mathrm{nmol} / 1$ 25(OH)D after adjustment for age, parity, smoking during pregnancy, maternal weight, previously diagnosed hypertension, diabetes, season at sampling, country of birth or socio-economic disadvantage (52). Furthermore, in 1953 women in southern China, vitamin D sufficiency $(25(\mathrm{OH}) \mathrm{D}$ of $>75 \mathrm{nmol} / \mathrm{l})$ at 16-20 weeks gestation was associated with a small, but statistically significant, increased risk of GDM (OR 1.02, 95\% CI 1.00, 1.04) (44).

\section{Caesarean delivery}

Unsurprisingly, in recent years, there has also been an increase in studies that have reported maternal vitamin $\mathrm{D}$ status in relation to the mode and timing of delivery. 


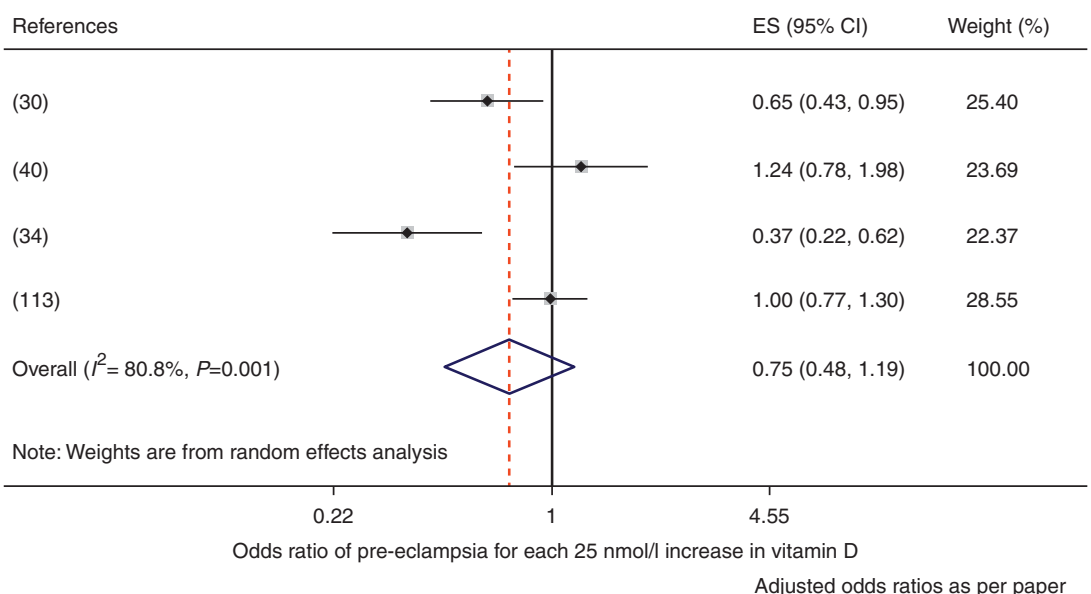

\section{Figure 1}

Forest plot of the association between maternal vitamin D status and risk of pre-eclampsia (observational studies).

Reproduced from Harvey N, Holroyd C, Ntani G, Javaid M,

Again, these are inconsistent. After adjusting for potential confounding factors, three studies, which assessed $25(\mathrm{OH}) \mathrm{D}$ in early pregnancy, when attending for GDM screening and at delivery, reported an increased risk of Caesarean delivery $(68,71,72)$. Conversely, two studies which measured $25(\mathrm{OH}) \mathrm{D}$ in the first trimester demonstrated no increased risk $(42,44)$. Assessment of the influence of VDD on the mode of delivery is further complicated by the underlying cause for intervention. Savvidou et al. (73) additionally categorised women requiring emergency caesarean delivery as a result of a failure to progress and for fetal distress. Neither group had significantly different serum 25(OH)D levels in early pregnancy from those of women who delivered vaginally (73).

\section{Preterm delivery}

More studies have concluded that maternal 25(OH)D status is not related to preterm birth $(39,42,52,74,75,76,77,78)$ than have shown that VDD increases this risk $(68,79,80)$. Furthermore, Zhou et al. (44) reported that women with higher vitamin D status at 16-20 weeks gestation had a higher odds of preterm delivery, and Hossain et al. (81) similarly found that cord blood $25(\mathrm{OH}) \mathrm{D}$ was higher in preterm (<37 weeks gestation) deliveries (mean $55 \mathrm{nmol} / \mathrm{l}$ ) as compared to term pregnancies (mean $40 \mathrm{nmol} / \mathrm{l}$, $P=0.009$ ) in women in Pakistan. Interestingly, two of the studies which suggested that VDD increased the risk of preterm delivery used a definition of $<35$ weeks gestation for preterm $(79,80)$, whereas all but one $(78)$ of the studies
Cooper P, Moon R, Cole Z, Tinati T, Godfrey K, Dennison E et al. Vitamin $D$ supplementation in pregnancy: a systematic review. Health Technology Assessment 201418 1-190.

which reported either no relationship or that VDD reduced the risk of preterm delivery considered preterm delivery to be at $<37$ weeks gestation. Although this might suggest that VDD is particularly associated with an increased risk of very preterm birth, Schneuer et al. (52), who prospectively studied first trimester $25(\mathrm{OH}) \mathrm{D}$ status in more than 5000 women, found that VDD did not increase the risk of either all or spontaneous preterm birth at $<34$ weeks gestation before or after adjustment for potential confounding factors. However, differences in the timing of $25(\mathrm{OH}) \mathrm{D}$ assessment, and the inclusion of only twin pregnancies in one study that showed increased risk (79), could account for these different findings. Furthermore, Bodnar et al. (80) observed that only non-white mothers had an increased risk of preterm birth with low 25(OH)D at 26 weeks gestation, which suggests that the stratification of women by ethnicity in future intervention studies might be necessary.

\section{Intervention studies of vitamin D supplementation to reduce obstetric complications}

Observational data cannot confirm a causal effect of vitamin D or justify population-wide supplementation, particularly seeing as some studies have suggested possible detrimental effects of higher $25(\mathrm{OH}) \mathrm{D}(43,44,81)$. Because $25(\mathrm{OH}) \mathrm{D}$ status is primarily determined by environmental factors, confounding and reverse causality need to be considered, and differences in the covariates included in multivariate models might explain the inconsistent findings. For example, obese individuals 
25(OH)D concentration insufficiency and GDM by cut-off levels

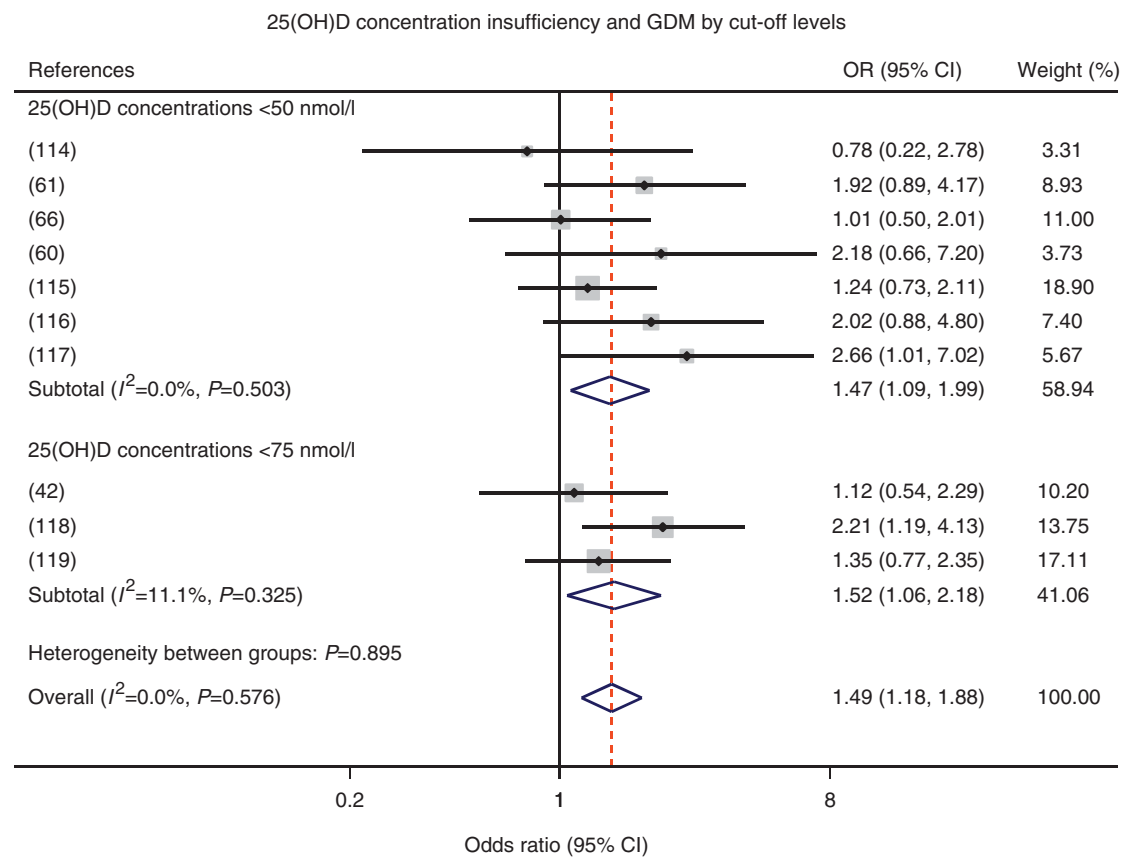

\section{Figure 2}

Meta-analysis of maternal serum 25(OH)D in pregnancy and gestational diabetes. Reproduced from Aghajafari $F_{\text {, }}$ Nagulesapillai T, Ronksley PE, Tough SC, O’Beirne M \& Rabi DM. Association between maternal serum 25-hydroxyvitamin $D$ level

have lower 25(OH)D status and a higher incidence of GDM, GHT, PET, caesarean section and preterm delivery $(82,83)$. Similarly African-American women are more likely to require delivery by Caesarean section and to experience pre-eclampsia and preterm labour (84). Whether these outcomes can truly be attributed to lower $25(\mathrm{OH}) \mathrm{D}$ as compared to Caucasian women and can therefore be prevented with vitamin $\mathrm{D}$ supplementation must be established through intervention studies.

Despite the expansiveness of the observational data, there are currently few trials of antenatal vitamin D supplementation that report on maternal outcomes other than maternal/neonatal vitamin D and calcium status (85). In three of the five studies, the interventional product contained only vitamin D $(26,86,87)$, whereas the other two assessed the effects of combined vitamin $\mathrm{D}$ and calcium supplementation $(88,89)$ (Table 2). The interpretation of these two studies with regards to GHT and PET is limited, because calcium supplementation is known to reduce the risk of PET (29). Nonetheless, high-dose vitamin D supplementation, with or without calcium supplementation, did not improve the incidence of GHT, PET, GDM, or preterm delivery as compared to either usual care and pregnancy and neonatal outcomes: systematic review and meta-analysis of observational studies. BMJ $2013346 \mathrm{f} 1169$. doi: 10.1136/bmj.f1169 with permission from BMJ Publishing Group Ltd.

or low-dose supplementation $(26,86,87,88,89)$. However, these studies were most likely underpowered to detect a difference in these outcomes. GDM complicates $\sim 4.5 \%$ of pregnancies in the UK (90). Thus, to detect a 50\% reduction in this incidence with $80 \%$ power at the $5 \%$ significance level, 1010 women would have been needed in each study arm. Because PET occurs in 2-3\% of pregnancies, even larger study numbers would be needed to detect it.

Although trials of vitamin D supplementation have not yet demonstrated a reduction in the incidence of PET or GDM, there is some evidence to support its effects on blood pressure and glucose metabolism when they are considered as continuous outcomes. For example, Marya et al. (89) demonstrated a reduction in both systolic and diastolic BP in women randomised to vitamin $\mathrm{D}$ and calcium supplementation as compared to those who received usual care. Confirmation of this finding using vitamin $\mathrm{D}$ alone is now needed. Three studies have assessed the effects of vitamin D supplementation on insulin resistance. In an unblinded study of 113 Iranian women randomised to one of three treatment groups (200 IU/day, $50000 \mathrm{IU} /$ month, $50000 \mathrm{IU} /$ fortnight) from 12 weeks gestation until delivery, insulin resistance, as 


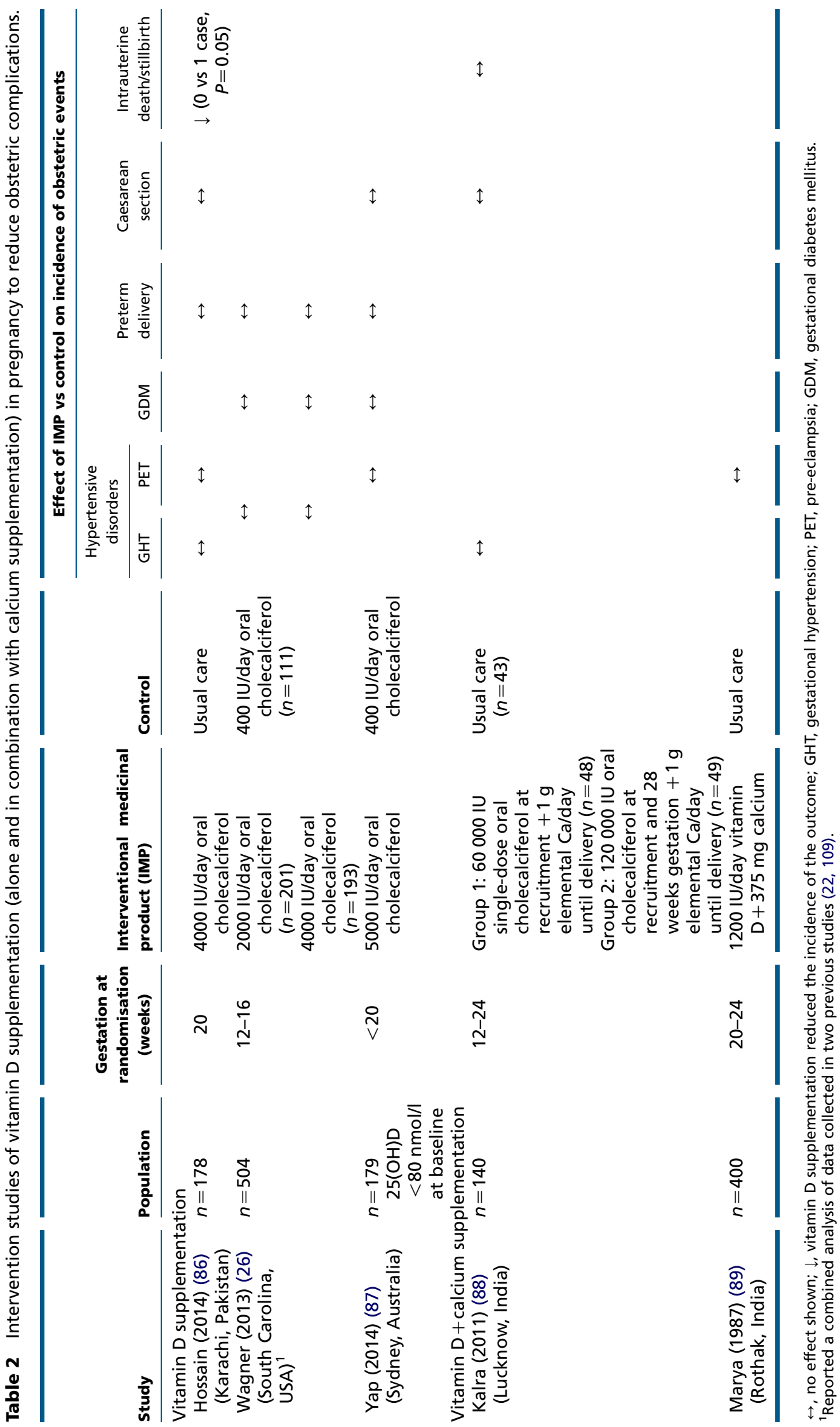


assessed by HOMA-IR, increased significantly from baseline to delivery in all three groups, but the rise was significantly less in women randomised to $50000 \mathrm{IU} /$ fortnight than it was in women who received $200 \mathrm{IU} /$ day (91). In contrast, Yap et al. (87) found no difference in either fasting blood glucose or that measured $2 \mathrm{~h}$ after glucose load in women randomised to either $400 \mathrm{IU} /$ day or $5000 \mathrm{IU} /$ day cholecalciferol, with similar results for HOMA-IR. Finally, in a small study of 54 women with a diagnosis of GDM, two doses of $50000 \mathrm{IU}$ cholecalciferol 3 weeks apart improved fasting blood glucose and insulin resistance as compared to a placebo. However, the women randomised to vitamin D supplementation had significantly higher insulin resistance at baseline, which makes these results difficult to interpret (92). Nonetheless, these findings support the need for further high-quality, large randomised controlled trials and the need to concurrently determine if any effects on maternal physiology might also have beneficial effects on maternal and/or fetal morbidity, for example, macrosomia or neonatal hypoglycaemia.

\section{Fetal development}

Early rickets and symptomatic neonatal hypocalcaemia have been reported in infants born to mothers with VDD $(93,94,95)$. However, these outcomes are rarely reported in infants of white mothers, and they most commonly occur in those born to mothers with dark skin pigmentation, extensive skin covering and profound VDD. The fetus is dependent on the mother for the accretion of $\sim 30 \mathrm{~g}$ of calcium to enable skeletal development. As such, a subclinical role for vitamin $\mathrm{D}$ and/or calcium in fetal growth and bone development has been considered, yet maternal supplementation with calcium alone does not appear to have beneficial effects on fetal bone mineral accrual (85).

\section{Size at birth}

There are now a number of intervention studies that have assessed the effect of vitamin D supplementation on birth anthropometry, although the dose and timing of introduction of vitamin D have varied widely (Table 3). Most of the studies trialled supplementation with vitamin D alone and did not find a significant effect on birth weight, length or head circumference (Table 1). However, interestingly, vitamin D in combination with calcium did increase birth weight in three studies despite women in the control group also receiving calcium supplementation in two of these studies $(88,96,97)$. Indeed, the prevalence of VDD at baseline and the mean 25(OH)D achieved were similar in a study of women in Bangladesh who received $35000 \mathrm{IU} /$ day cholecalciferol from 26 to 30 weeks gestation (24) to those in women who participated in a study of 50000 IU cholecalciferol per week in addition to $200 \mathrm{mg}$ elemental calcium supplementation in Iran (97). Both studies included a similar number of women. However, in the former study, birth weight was similar in both the intervention and control groups, whereas in the latter study, mean birth weight in the intervention group was $170 \mathrm{~g}$ greater than that in the control group. These differing findings might suggest that the effect of vitamin D is dependent on the availability of calcium, or they could result from genetic/racial variation in response to vitamin D supplementation, but they nonetheless highlight the importance of using data obtained from an appropriate population in the development of antenatal supplementation policies.

\section{Skeletal development}

Currently, the data relating maternal $25(\mathrm{OH}) \mathrm{D}$ status to offspring bone development is largely observational in nature, but they do span antenatal measurements to peak bone mass. Indeed, using gestational ultrasound, smaller femoral volumes (98) and widening of the distal femoral metaphysis relative to femur length have been demonstrated in fetuses of mothers with low levels of serum 25(OH)D (99).

A number of studies have demonstrated associations between maternal $25(\mathrm{OH}) \mathrm{D}$ status in pregnancy and offspring bone mineralisation during the neonatal period. In 71 Korean neonates, those born in the summer (JulySeptember) had a whole-body bone mineral content (BMC) that was $6 \%$ higher than that of infants born in the winter (January-March), and neonatal $25(\mathrm{OH}) \mathrm{D}$ at delivery was correlated with whole-body BMC in all children ( $r=0.24, P=0.05)$ (100). However, in three similar studies by the same authors in North America, a reversed pattern was observed, with whole-body BMC being $8-12 \%$ lower in infants born in the summer (101). The authors suggest that this difference reflects a low uptake of vitamin D supplementation throughout pregnancy in Korea but only during the first trimester in North America, which therefore indicates that early pregnancy during winter might impact skeletal development (101). However, Weiler et al. (102) studied 50 Canadian infants born between August and April, with the majority of mothers taking vitamin $\mathrm{D}$ supplementation during pregnancy. Infants with a cord blood $25(\mathrm{OH}) \mathrm{D}$ of $<37.5 \mathrm{nmol} / \mathrm{l}(n=18)$ were heavier and longer than 


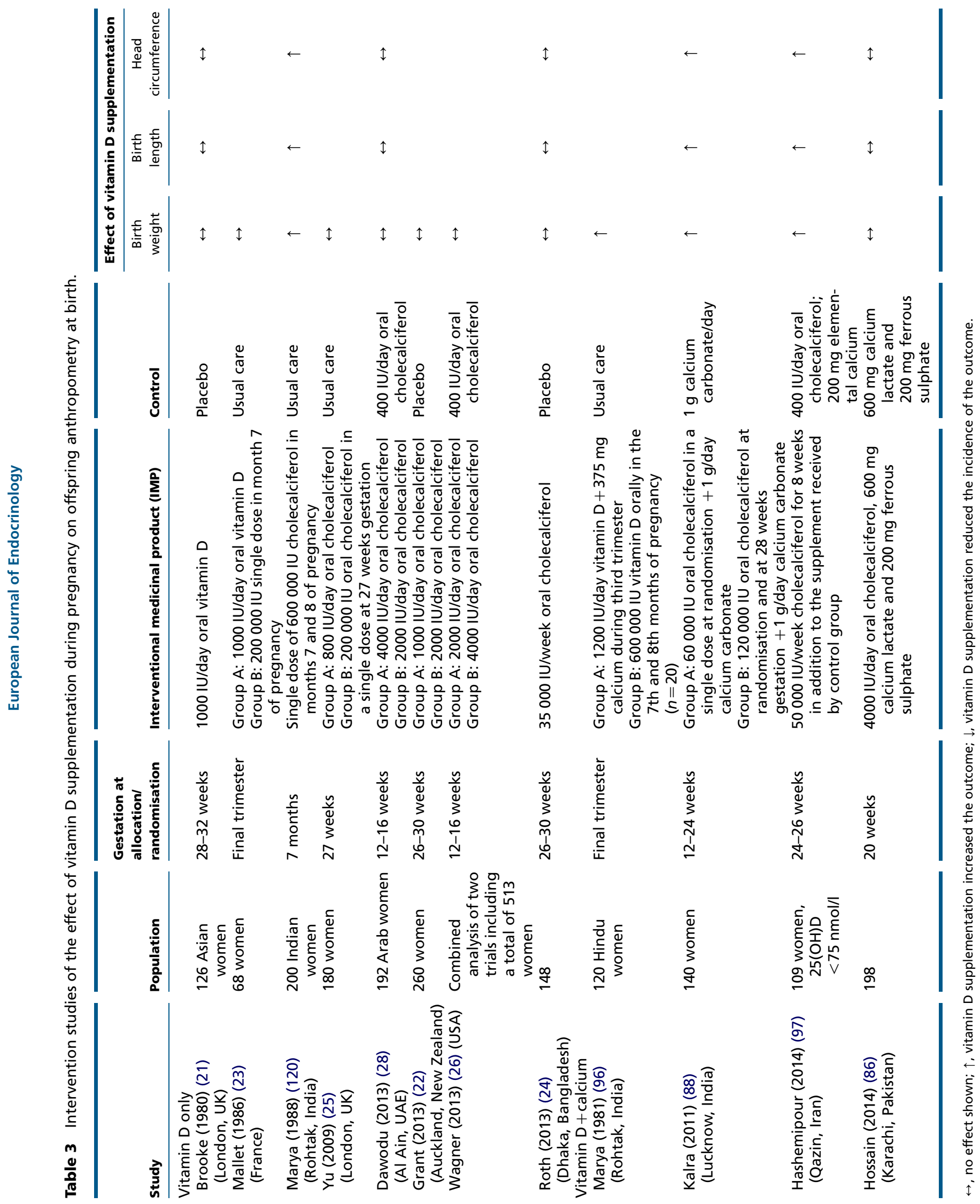


those with a cord blood 25(OH)D above this cut-point were, but skeletal size was not relatively increased, such that whole-body and femur BMC relative to body weight were significantly lower (102). In a Finnish study, peripheral quantitative computed tomography (pQCT) was used to assess both BMC and bone geometry of the tibia in 98 neonates. In that analysis, the mean of two maternal 25(OH)D measurements in early pregnancy and 2 days postpartum was used to define maternal vitamin D status, and the median for the cohort was used to establish two groups. BMC and bone cross-sectional area (CSA) were 13.9 and $16.3 \%$ higher respectively in infants of mothers with higher 25(OH)D (103). When these children were reassessed at 14 months of age, the difference in tibial BMC was no longer present, but the greater CSA had persisted (104). Conversely, in 125 Gambian mother-offspring pairs, no significant relationships were observed between maternal 25(OH)D at either 20 or 36 weeks gestation and offspring whole-body BMC or bone area at 2, 13 or 52 weeks of age (105). However, in contrast to the other studies, none of the mothers had a $25(\mathrm{OH}) \mathrm{D}$ of $<50 \mathrm{nmol} / \mathrm{l}$, which is consistent with the notion that poorer skeletal mineralisation might only occur in fetuses of mothers with the lowest vitamin D levels.

There is evidence to support the persistence of these relationships outside of the neonatal period, although the data are less consistent. In the first study to report on the relationship between maternal 25(OH)D status and offspring bone mineralisation in childhood, Javaid et al. (15) demonstrated positive associations between late pregnancy $25(\mathrm{OH}) \mathrm{D}$ and offspring whole-body and lumbar spine BMC, bone area and areal bone mineral density (aBMD) measured at 9 years (Fig. 3). Positive relationships with umbilical venous calcium concentration were also observed, which suggests that the effect of vitamin D on skeletal development might be mediated through placental calcium transport (15). This was initially supported by data from the Avon Longitudinal Study of Parents and Children (ALSPAC), in which maternal estimated u.v. B exposure in late pregnancy, which was used as a proxy measure of vitamin D status, was positively associated with offspring whole-body less head (WBLH) BMC and bone area at 9-10 years of age in 6955 children (106). However, subsequent reanalysis in a more limited subset of the ALSPAC cohort using serum 25(OH)D measured in pregnancy demonstrated no association with WBLH BMC or bone area (107). Interestingly, there was strong collinearly between maternal gestational u.v. B exposure and offspring age at bone assessment, which limits the interpretation of these studies (108). Finally, data from the Raine cohort in Western Australia provide support for

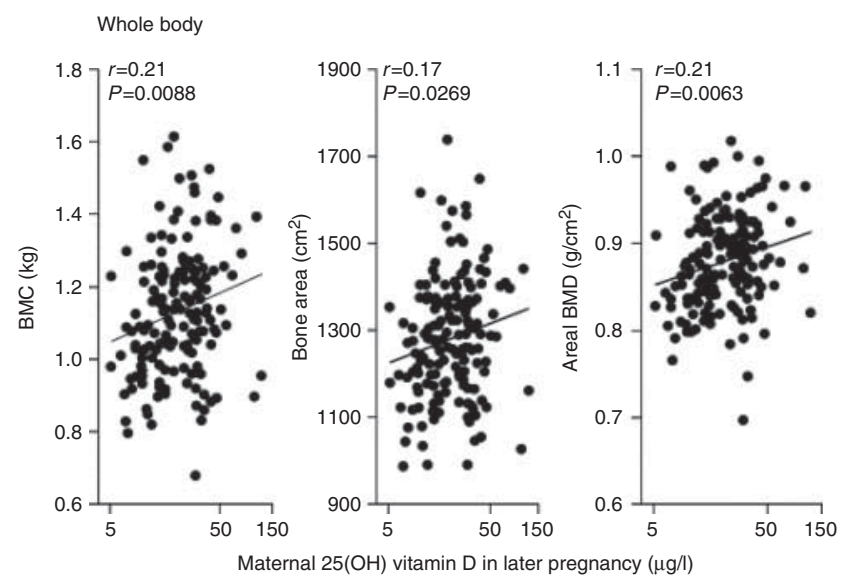

Figure 3

Maternal 25(OH)D concentration in late pregnancy and childhood bone mass at age 9 years. Reprinted from Javaid MK, Crozier SR, Harvey NC, Gale CR, Dennison EM, Boucher BJ, Arden NK, Godfrey KM \& Cooper C. Maternal vitamin D status during pregnancy and childhood bone mass at age 9 years: a longitudinal study. Lancet 2006367 36-43, Copyright (2014), with permission from Elsevier.

a positive relationship between maternal gestational vitamin D status and offspring bone development to peak bone mass (109). In that study, whole-body BMC and aBMD were 2.7 and $1.7 \%$ lower respectively at 20 years of age in the offspring of mothers with $25(\mathrm{OH}) \mathrm{D}$ of $<50 \mathrm{nmol} / \mathrm{l}$ (as compared to the offspring of mothers with $>50 \mathrm{nmol} / \mathrm{l}$ ) at 18 weeks gestation after adjustment for sex, age, height and body composition at 20 years, maternal height and prepregnancy weight, age at delivery, parity, education, ethnicity, smoking during pregnancy and season of maternal blood sampling.

Currently there is only one intervention study of the effects of vitamin D supplementation during pregnancy on offspring bone mineralisation. Congdon et al. (110) assessed forearm BMC using single-photon absorptiometry in 64 infants of Asian mothers living in the UK who participated in a non-randomised study of vitamin D and calcium supplementation during pregnancy. Nineteen women received $1000 \mathrm{IU}$ vitamin D and a calcium supplement (of unknown strength) during the final trimester and were compared to 45 women who did not receive any supplementation. No significant differences were identified between these two groups, but interpretation of the study findings is limited by the small study size, the lack of randomisation and the technique used to assess BMC. The ongoing Maternal Vitamin D 
Osteoporosis Study (MAVIDOS), in which more than 1000 women were randomised to $1000 \mathrm{IU}$ cholecalciferol or placebo daily from 14 weeks gestation until delivery and in which offspring bone mineralisation were assessed at birth and at 4 years of age by dual energy X-ray absorptiometry (DXA) (111), will provide much-needed high-quality evidence on the role of vitamin D supplementation during pregnancy in fetal skeletal development (112).

\section{Conclusion}

There is now a wealth of observational data relating vitamin D status in pregnancy to obstetric complications, fetal growth and offspring bone development. The findings of these studies are inconsistent, and although they justify the need for assessing vitamin D supplementation in high-quality randomised controlled trials, observational data alone should not be used as a basis for population-wide vitamin $\mathrm{D}$ supplementation during pregnancy. Indeed, it is possible that the variability in findings of both observational and a few intervention studies reflects the wide heterogeneity in the populations studied (including the prevalence of VDD, calcium status and ethnic diversity), the dose of vitamin $\mathrm{D}$, the timing of initiation or the assessment of $25(\mathrm{OH}) \mathrm{D}$ status and the definition used for the outcomes considered. Thus, any public health recommendations need to be based on an appropriate population. Furthermore, although the currently available data do not suggest any short-term detrimental effects on the mother or fetus, the long-term safety of vitamin D supplementation, particularly at supra-physiological doses, remains to be established.

\section{Declaration of interest}

N C Harvey received consultancy, lecture fees and honoraria from the Alliance for Better Bone Health, AMGEN, MSD, Eli Lilly, Servier, Shire, Consilient Healthcare and Internis Pharma; C Cooper received consultancy, lecture fees and honoraria from AMGEN, GSK, Alliance for Better Bone Health, MSD, Eli Lilly, Pfizer, Novartis, Servier, Medtronic and Roche.

\section{Funding}

The authors are grateful to the UK Medical Research Council, Arthritis Research UK, the NIHR HTA programme and the International Osteoporosis Foundation, for their support of this work.

\section{References}

1 National Institute for Health and Clincial Excellence. Antenatal care (NICE Clinical Guideline 62). www.guidance.nice.org.uk/cg62, 2010.
2 Paxton GA, Teale GR, Nowson CA, Mason RS, McGrath JJ, Thompson MJ, Siafarikas A, Rodda CP \& Munns CF. Vitamin D and health in pregnancy, infants, children and adolescents in Australia and New Zealand: a position statement. Medical Journal of Australia 2013198 142-143. (doi:10.5694/mja11.11592)

3 Holick MF, Binkley NC, Bischoff-Ferrari HA, Gordon CM, Hanley DA, Heaney RP, Murad MH \& Weaver CM. Evaluation, treatment, and prevention of vitamin D deficiency: an Endocrine Society clinical practice guideline. Journal of Clinical Endocrinology and Metabolism 201196 1911-1930. (doi:10.1210/jc.2011-0385)

4 World Health Organisation. Guideline: Vitamin D supplementation in pregnant women. Geneva, 2012. Available online: http://www.who. int/nutrition/publications/micronutrients/guidelines/vit_d_supp_ pregnant_women/en/

5 Harvey N, Holroyd C, Ntani G, Javaid M, Cooper P, Moon R, Cole Z, Tinati T, Godfrey K, Dennison E et al. Vitamin D supplementation in pregnancy: a systematic review. Health Technology Assessment 201418 1-190. (doi:10.3310/hta18450)

6 Jones KS, Assar S, Harnpanich D, Bouillon R, Lambrechts D, Prentice A \& Schoenmakers I. 25(OH)D2 half-life is shorter than 25(OH)D3 half-life and is influenced by DBP concentration and genotype. Journal of Clinical Endocrinology and Metabolism 201499 3373-3381. (doi:10.1210/jc.2014-1714)

7 Hollis BW \& Wagner CL. Clinical review: The role of the parent compound vitamin $\mathrm{D}$ with respect to metabolism and function: why clinical dose intervals can affect clinical outcomes. Journal of Clinical Endocrinology and Metabolism 201398 4619-4628. (doi:10.1210/jc.2013-2653)

8 Bikle D, Adams JS \& Christakos S. Vitamin D: production, metabolism, mechanism of action, and clinical requirements. In Primer on the Metabolic Bone Diseases and Disorders of Mineral Metabolism, pp 235-248: John Wiley \& Sons, Inc., 2013.

9 Kovacs CS. Calcium and bone metabolism in pregnancy and lactation*. Journal of Clinical Endocrinology and Metabolism 200186 2344-2348. (doi:10.1210/jcem.86.6.7575)

10 Cross NA, Hillman LS, Allen SH, Krause GF \& Vieira NE. Calcium homeostasis and bone metabolism during pregnancy, lactation, and postweaning: a longitudinal study. American Journal of Clinical Nutrition 199561 514-523.

11 Ritchie LD, Fung EB, Halloran BP, Turnlund JR, Van Loan MD, Cann CE \& King JC. A longitudinal study of calcium homeostasis during human pregnancy and lactation and after resumption of menses. American Journal of Clinical Nutrition 199867 693-701.

12 More C, Bhattoa HP, Bettembuk P \& Balogh A. The effects of pregnancy and lactation on hormonal status and biochemical markers of bone turnover. European Journal of Obstetrics, Gynecology, and Reproductive Biology 2003106 209-213. (doi:10.1016/S0301-2115(02)00237-3)

13 Ardawi MS, Nasrat HA \& BA'Aqueel HS. Calcium-regulating hormones and parathyroid hormone-related peptide in normal human pregnancy and postpartum: a longitudinal study. European Journal of Endocrinology/European Federation of Endocrine Societies 1997137 402-409. (doi:10.1530/eje.0.1370402)

14 Zhang JY, Lucey AJ, Horgan R, Kenny LC \& Kiely M. Impact of pregnancy on vitamin D status: a longitudinal study. British Journal of Nutrition 2014112 1081-1087. (doi:10.1017/S0007114514001883)

15 Javaid MK, Crozier SR, Harvey NC, Gale CR, Dennison EM, Boucher BJ, Arden NK, Godfrey KM \& Cooper C. Maternal vitamin D status during pregnancy and childhood bone mass at age 9 years: a longitudinal study. Lancet 2006367 36-43. (doi:10.1016/S0140-6736(06)67922-1)

16 McAree T, Jacobs B, Manickavasagar T, Sivalokanathan S, Brennan L, Bassett P, Rainbow S \& Blair M. Vitamin D deficiency in pregnancy still a public health issue. Maternal \& Child Nutrition 20139 23-30. (doi:10.1111/mcn.12014)

17 Maghbooli Z, Hossein-Nezhad A, Shafaei AR, Karimi F, Madani FS \& Larijani B. Vitamin D status in mothers and their newborns in Iran. BMC Pregnancy and Childbirth 20077 1. (doi:10.1186/1471-2393-7-1) 
18 Song SJ, Si S, Liu J, Chen X, Zhou L, Jia G, Liu G, Niu Y, Wu J, Zhang W et al. Vitamin D status in Chinese pregnant women and their newborns in Beijing and their relationships to birth size. Public Health Nutrition 201316 687-692. (doi:10.1017/S1368980012003084)

19 Markestad T, Aksnes L, Ulstein M \& Aarskog D. 25-Hydroxyvitamin D and 1,25-dihydroxyvitamin D of D2 and D3 origin in maternal and umbilical cord serum after vitamin D2 supplementation in human pregnancy. American Journal of Clinical Nutrition 198440 1057-1063.

20 Novakovic B, Galati JC, Chen A, Morley R, Craig JM \& Saffery R. Maternal vitamin $\mathrm{D}$ predominates over genetic factors in determining neonatal circulating vitamin D concentrations. American Journal of Clinical Nutrition 201296 188-195. (doi:10.3945/ajcn.112.035683)

21 Brooke OG, Brown IR, Bone CD, Carter ND, Cleeve HJ, Maxwell JD, Robinson VP \& Winder SM. Vitamin D supplements in pregnant Asian women: effects on calcium status and fetal growth. BMJ $1980 \mathbf{2 8 0}$ 751-754. (doi:10.1136/bmj.280.6216.751)

22 Grant CC, Stewart AW, Scragg R, Milne T, Rowden J, Ekeroma A, Wall C, Mitchell EA, Crengle S, Trenholme A et al. Vitamin D during pregnancy and infancy and infant serum 25-hydroxyvitamin D concentration. Pediatrics 2014133 e143-53. (doi:10.1542/peds.2013-2602)

23 Mallet E, Gugi B, Brunelle P, Henocq A, Basuyau JP \& Lemeur H. Vitamin D supplementation in pregnancy: a controlled trial of two methods. Obstetrics and Gynecology 198668 300-304. (doi:10.1097/ 00006250-198609000-00002)

24 Roth DE, Al Mahmud A, Raqib R, Akhtar E, Perumal N, Pezzack B \& Baqui AH. Randomized placebo-controlled trial of high-dose prenatal third-trimester vitamin D3 supplementation in Bangladesh: the AViDD trial. Nutrition Journal 201312 47. (doi:10.1186/14752891-12-47)

25 Yu CK, Sykes L, Sethi M, Teoh TG \& Robinson S. Vitamin D deficiency and supplementation during pregnancy. Clinical Endocrinology 2009 70 685-690. (doi:10.1111/j.1365-2265.2008.03403.x)

26 Wagner CL, McNeil RB, Johnson DD, Hulsey TC, Ebeling M, Robinson C, Hamilton SA \& Hollis BW. Health characteristics and outcomes of two randomized vitamin D supplementation trials during pregnancy: a combined analysis. Journal of Steroid Biochemistry and Molecular Biology 2013136 313-320. (doi:10.1016/j.jsbmb.2013.01.002)

27 Hollis BW, Johnson D, Hulsey TC, Ebeling M \& Wagner CL. Vitamin D supplementation during pregnancy: double-blind, randomized clinical trial of safety and effectiveness. Journal of Bone and Mineral Research 201126 2341-2357. (doi:10.1002/jbmr.463)

28 Dawodu A, Saadi HF, Bekdache G, Javed Y, Altaye M \& Hollis BW. Randomized controlled trial (RCT) of vitamin D supplementation in pregnancy in a population with endemic vitamin D deficiency. Journal of Clinical Endocrinology and Metabolism 201398 2337-2346. (doi:10.1210/jc.2013-1154)

29 Hofmeyr GJ, Lawrie TA, Atallah AN, Duley L \& Torloni MR. Calcium supplementation during pregnancy for preventing hypertensive disorders and related problems. Cochrane Database of Systematic Reviews 20146 Cd001059. (doi:10.1002/14651858.CD001059.pub4)

30 Bodnar LM, Catov JM, Simhan HN, Holick MF, Powers RW \& Roberts JM. Maternal vitamin D deficiency increases the risk of preeclampsia. Journal of Clinical Endocrinology and Metabolism 200792 3517-3522. (doi:10.1210/jc.2007-0718)

31 Baker AM, Haeri S, Camargo CA Jr, Espinola JA \& Stuebe AM. A nested case-control study of midgestation vitamin D deficiency and risk of severe preeclampsia. Journal of Clinical Endocrinology and Metabolism 201095 5105-5109. (doi:10.1210/jc.2010-0996)

32 Bodnar LM, Simhan HN, Catov JM, Roberts JM, Platt RW, Diesel JC \& Klebanoff MA. Maternal vitamin D status and the risk of mild and severe preeclampsia. Epidemiology 201425 207-214. (doi:10.1097/ EDE.0000000000000039)

33 Wei SQ, Audibert F, Hidiroglou N, Sarafin K, Julien P, Wu Y, Luo ZC \& Fraser WD. Longitudinal vitamin D status in pregnancy and the risk of pre-eclampsia. BJOG 2012119 832-839. (doi:10.1111/j.1471-0528. 2012.03307.x)
34 Robinson CJ, Alanis MC, Wagner CL, Hollis BW \& Johnson DD Plasma 25-hydroxyvitamin D levels in early-onset severe preeclampsia. American Journal of Obstetrics and Gynecology 2010203 366e1-6. (doi:10.1016/j.ajog.2010.06.036)

$35 \mathrm{Xu}$ L, Lee M, Jeyabalan A \& Roberts JM. The relationship of hypovitaminosis D and IL-6 in preeclampsia. American Journal of Obstetrics and Gynecology 2014210 149e1-7. (doi:10.1016/j.ajog.2013.09.037)

36 Abedi P, Mohaghegh Z, Afshary P \& Latifi M. The relationship of serum vitamin D with pre-eclampsia in the Iranian women. Maternal \& Child Nutrition 201410 206-212. (doi:10.1111/mcn.12058)

37 Scholl TO, Chen X \& Stein TP. Vitamin D, secondary hyperparathyroidism, and preeclampsia. American Journal of Clinical Nutrition 201398 787-793. (doi:10.3945/ajcn.112.055871)

38 Haugen M, Brantsaeter AL, Trogstad L, Alexander J, Roth C, Magnus P \& Meltzer HM. Vitamin D supplementation and reduced risk of preeclampsia in nulliparous women. Epidemiology 200920 720-726. (doi:10.1097/EDE.0b013e3181a70f08)

39 Shand AW, Nassar N, Von Dadelszen P, Innis SM \& Green TJ. Maternal vitamin $\mathrm{D}$ status in pregnancy and adverse pregnancy outcomes in a group at high risk for pre-eclampsia. BJOG 2010117 1593-1598. (doi:10.1111/j.1471-0528.2010.02742.x)

40 Powe CE, Seely EW, Rana S, Bhan I, Ecker J, Karumanchi SA \& Thadhani R. First trimester vitamin D, vitamin D binding protein, and subsequent preeclampsia. Hypertension 201056 758-763. (doi:10.1161/HYPERTENSIONAHA.110.158238)

41 Seely EW, Wood RJ, Brown EM \& Graves SW. Lower serum ionized calcium and abnormal calciotropic hormone levels in preeclampsia. Journal of Clinical Endocrinology and Metabolism 199274 1436-1440. (doi:10.1210/jcem.74.6.1592891)

42 Fernandez-Alonso AM, Dionis-Sanchez EC, Chedraui P, GonzalezSalmeron MD \& Perez-Lopez FR. First-trimester maternal serum 25-hydroxyvitamin $\mathrm{D}(3)$ status and pregnancy outcome. International Journal of Gynaecology and Obstetrics 2012116 6-9. (doi:10.1016/j.ijgo. 2011.07.029)

43 Burris HH, Rifas-Shiman SL, Huh SY, Kleinman K, Litonjua AA, Oken E, Rich-Edwards JW, Camargo CA Jr \& Gillman MW. Vitamin D status and hypertensive disorders in pregnancy. Annals of Epidemiology 201424 399-403.e1. (doi:10.1016/j.annepidem.2014.02.001)

44 Zhou J, Su L, Liu M, Liu Y, Cao X, Wang Z \& Xiao H. Associations between 25-hydroxyvitamin $\mathrm{D}$ levels and pregnancy outcomes: a prospective observational study in southern China. European Journal of Clinical Nutrition 201468 925-930. (doi:10.1038/ejcn.2014.99)

45 Dalmar A, Raff H, Chauhan SP, Singh M \& Siddiqui DS. Serum 25-hydroxyvitamin D, calcium, and calcium-regulating hormones in preeclamptics and controls during first day postpartum. Endocrine 2015 48 287-292. (doi:10.1007/s12020-014-0296-9)

46 Yu CK, Ertl R, Skyfta E, Akolekar R \& Nicolaides KH. Maternal serum vitamin D levels at 11-13 weeks of gestation in preeclampsia. Journal of Human Hypertension 201327 115-118. (doi:10.1038/jhh.2012.1)

47 Hypponen E, Cavadino A, Williams D, Fraser A, Vereczkey A, Fraser WD, Banhidy F, Lawlor D \& Czeizel AE. Vitamin D and preeclampsia: original data, systematic review and meta-analysis. Annals of Nutrition \& Metabolism 201363 331-340. (doi:10.1159/000358338)

48 Thorne-Lyman A \& Fawzi WW. Vitamin D during pregnancy and maternal, neonatal and infant health outcomes: a systematic review and meta-analysis. Paediatric and Perinatal Epidemiology 201226 (Suppl 1) 75-90. (doi:10.1111/j.1365-3016.2012.01283.x)

49 Aghajafari F, Nagulesapillai T, Ronksley PE, Tough SC, O’Beirne M \& Rabi DM. Association between maternal serum 25-hydroxyvitamin D level and pregnancy and neonatal outcomes: systematic review and meta-analysis of observational studies. BMJ 2013346 f1169. (doi:10.1136/bmj.f1169)

50 Tabesh M, Salehi-Abargouei A, Tabesh M \& Esmaillzadeh A. Maternal vitamin D status and risk of pre-eclampsia: a systematic review and meta-analysis. Journal of Clinical Endocrinology and Metabolism 201398 3165-3173. (doi:10.1210/jc.2013-1257) 
51 Wei SQ, Qi HP, Luo ZC \& Fraser WD. Maternal vitamin D status and adverse pregnancy outcomes: a systematic review and meta-analysis. Journal of Maternal-Fetal \& Neonatal Medicine 201326 889-899. (doi:10.3109/14767058.2013.765849)

52 Schneuer FJ, Roberts CL, Guilbert C, Simpson JM, Algert CS, Khambalia AZ, Tasevski V, Ashton AW, Morris JM \& Nassar N. Effects of maternal serum 25-hydroxyvitamin D concentrations in the first trimester on subsequent pregnancy outcomes in an Australian population. American Journal of Clinical Nutrition 201499 287-295. (doi:10.3945/ajcn.113.065672)

53 Reeves IV, Bamji ZD, Rosario GB, Lewis KM, Young MA \& Washington KN. Vitamin D deficiency in pregnant women of ethnic minority: a potential contributor to preeclampsia. Journal of Perinatology 201434 767-773. (doi:10.1038/jp.2014.91)

54 Xu L, Nicholson P, Wang Q, Alen M \& Cheng S. Bone and muscle development during puberty in girls: a seven-year longitudinal study. Journal of Bone and Mineral Research 200924 1693-1698. (doi:10.1359/ jbmr.090405)

55 Bener A, Al-Hamaq AO \& Saleh NM. Association between vitamin D insufficiency and adverse pregnancy outcome: global comparisons. International Journal of Women's Health 20135 523-531. (doi:10.2147/ IJWH.S51403)

56 Wetta LA, Biggio JR, Cliver S, Abramovici A, Barnes S \& Tita AT. Is midtrimester vitamin D status associated with spontaneous preterm birth and preeclampsia? American Journal of Perinatology 201431 541-546. (doi:10.1055/s-0033-1356483)

57 Ullah MI, Koch CA, Tamanna S, Rouf S \& Shamsuddin L. Vitamin D deficiency and the risk of preeclampsia and eclampsia in Bangladesh. Hormone and Metabolic Research 201345 682-687. (doi:10.1055/ s-0033-1345199)

58 Robinson CJ, Wagner CL, Hollis BW, Baatz JE \& Johnson DD. Association of maternal vitamin $\mathrm{D}$ and placenta growth factor with the diagnosis of early onset severe preeclampsia. American Journal of Perinatology 201330 167-172. (doi:10.1055/s-0032-1322514)

59 Anderson CM, Ralph J, Johnson L, Scheett A, Wright ML, Taylor JY, Ohm JE \& Uthus E. First trimester vitamin D status and placental epigenomics in preeclampsia among Northern Plains primiparas. Life Sciences 2014 pii: S0024-3205 00621-00623. (doi:10.1016/j.lfs.2014. 07.012)

60 Maghbooli Z, Hossein-Nezhad A, Karimi F, Shafaei AR \& Larijani B. Correlation between vitamin D3 deficiency and insulin resistance in pregnancy. Diabetes/Metabolism Research and Reviews 200824 27-32. (doi:10.1002/dmrr.737)

61 Clifton-Bligh RJ, McElduff P \& McElduff A. Maternal vitamin D deficiency, ethnicity and gestational diabetes. Diabetic Medicine 2008 25 678-684. (doi:10.1111/j.1464-5491.2008.02422.x)

62 Lacroix M, Battista MC, Doyon M, Houde G, Menard J, Ardilouze JL, Hivert MF \& Perron P. Lower vitamin D levels at first trimester are associated with higher risk of developing gestational diabetes mellitus. Acta Diabetologica 201451 609-616. (doi:10.1007/s00592-014-0564-4)

63 McManus R, Summers K, de Vrijer B, Cohen N, Thompson A \& Giroux I. Maternal, umbilical arterial and umbilical venous 25-hydroxyvitamin D and adipocytokine concentrations in pregnancies with and without gestational diabetes. Clinical Endocrinology 2014 80 635-641. (doi:10.1111/cen.12325)

64 Cho GJ, Hong SC, Oh MJ \& Kim HJ. Vitamin D deficiency in gestational diabetes mellitus and the role of the placenta. American Journal of Obstetrics and Gynecology 2013209 560.e1-8. (doi:10.1016/j. ajog.2013.08.015)

65 Wang O, Nie M, Hu YY, Zhang K, Li W, Ping F, Liu JT, Chen LM \& Xing XP. Association between vitamin D insufficiency and the risk for gestational diabetes mellitus in pregnant Chinese women. Biomedical and Environmental Sciences 201225 399-406. (doi:10.3967/0895-3988. 2012.04.004)

66 Farrant HJ, Krishnaveni GV, Hill JC, Boucher BJ, Fisher DJ, Noonan K, Osmond C, Veena SR \& Fall CH. Vitamin D insufficiency is common in
Indian mothers but is not associated with gestational diabetes or variation in newborn size. European Journal of Clinical Nutrition 200963 646-652. (doi:10.1038/ejcn.2008.14)

67 Whitelaw DC, Scally AJ, Tuffnell DJ, Davies TJ, Fraser WD, Bhopal RS, Wright J \& Lawlor DA. Associations of circulating calcium and 25-hydroxyvitamin D with glucose metabolism in pregnancy: a cross-sectional study in European and South Asian women. Journal of Clinical Endocrinology and Metabolism 201499 938-946.

68 Perez-Ferre N, Torrejon MJ, Fuentes M, Fernandez MD, Ramos A, Bordiu E, del Valle L, Rubio MA, Bedia AR, Montanez C et al. Association of low serum 25-hydroxyvitamin D levels in pregnancy with glucose homeostasis and obstetric and newborn outcomes. Endocrine Practice 201218 676-684. (doi:10.4158/EP12025.OR)

69 Poel YH, Hummel P, Lips P, Stam F, van der Ploeg T \& Simsek S. Vitamin D and gestational diabetes: a systematic review and metaanalysis. European Journal of Internal Medicine 201223 465-469. (doi:10.1016/j.ejim.2012.01.007)

70 Parildar H, Dogruk Unal A, Aksan Desteli G, Cigerli O \& Guvener Demirag N. Frequency of vitamin D deficiency in pregnant diabetics at Baskent University Hospital, Istanbul. Pakistan Journal of Medical Sciences 201329 15-20. (doi:10.12669/pjms.291.2896)

71 Merewood A, Mehta SD, Chen TC, Bauchner H \& Holick MF. Association between vitamin $\mathrm{D}$ deficiency and primary cesarean section. Journal of Clinical Endocrinology and Metabolism 200994 940-945. (doi:10.1210/jc.2008-1217)

72 Scholl TO, Chen X \& Stein P. Maternal vitamin D status and delivery by cesarean. Nutrients 20124 319-330. (doi:10.3390/nu4040319)

73 Savvidou MD, Makgoba M, Castro PT, Akolekar R \& Nicolaides KH. First-trimester maternal serum vitamin D and mode of delivery. British Journal of Nutrition 2012108 1972-1975. (doi:10.1017/ S0007114512000207)

74 Dunlop AL, Taylor RN, Tangpricha V, Fortunato S \& Menon R. Maternal micronutrient status and preterm versus term birth for black and white US women. Reproductive Sciences 201219 939-948. (doi:10.1177/1933719112438442)

75 Mehta S, Hunter DJ, Mugusi FM, Spiegelman D, Manji KP Giovannucci EL, Hertzmark E, Msamanga GI \& Fawzi WW. Perinatal outcomes, including mother-to-child transmission of HIV, and child mortality and their association with maternal vitamin D status in Tanzania. Journal of Infectious Diseases 2009200 1022-1030. (doi:10.1086/605699)

76 Delmas PD, Glorieux FH, Delvin EE, Salle BL \& Melki I. Perinatal serum bone Gla-protein and vitamin D metabolites in preterm and fullterm neonates. Journal of Clinical Endocrinology and Metabolism 198765 588-591. (doi:10.1210/jcem-65-3-588)

77 Thorp JM, Camargo CA, McGee PL, Harper M, Klebanoff MA, Sorokin Y, Varner MW, Wapner RJ, Caritis SN, Iams JD et al. Vitamin D status and recurrent preterm birth: a nested case-control study in high-risk women. BJOG 2012119 1617-1623. (doi:10.1111/ j.1471-0528.2012.03495.x)

78 Baker AM, Haeri S, Camargo CA Jr, Stuebe AM \& Boggess KA. A nested case-control study of first-trimester maternal vitamin D status and risk for spontaneous preterm birth. American Journal of Perinatology 2011 28 667-672. (doi:10.1055/s-0031-1276731)

79 Bodnar LM, Rouse DJ, Momirova V, Peaceman AM, Sciscione A, Spong CY, Varner MW, Malone FD, Iams JD, Mercer BM et al. Maternal 25-hydroxyvitamin D and preterm birth in twin gestations. Obstetrics and Gynecology 2013122 91-98. (doi:10.1097/AOG. Ob013e3182941d9a)

80 Bodnar LM, Klebanoff MA, Gernand AD, Platt RW, Parks WT, Catov JM \& Simhan HN. Maternal vitamin D status and spontaneous preterm birth by placental histology in the US Collaborative Perinatal Project. American Journal of Epidemiology 2014179 168-176. (doi:10.1093/aje/kwt237)

81 Hossain N, Khanani R, Hussain-Kanani F, Shah T, Arif S \& Pal L. High prevalence of vitamin D deficiency in Pakistani mothers and their 
newborns. International Journal of Gynaecology and Obstetrics 2011112 229-233. (doi:10.1016/j.ijgo.2010.09.017)

82 Li N, Liu E, Guo J, Pan L, Li B, Wang P, Liu J, Wang Y, Liu G, Baccarelli AA et al. Maternal prepregnancy body mass index and gestational weight gain on pregnancy outcomes. PLoS ONE $2013 \mathbf{8}$ e82310. (doi:10.1371/journal.pone.0082310)

83 Bautista-Castano I, Henriquez-Sanchez P, Aleman-Perez N, GarciaSalvador JJ, Gonzalez-Quesada A, Garcia-Hernandez JA \& Serra-Majem L. Maternal obesity in early pregnancy and risk of adverse outcomes. PLoS ONE 20138 e80410. (doi:10.1371/journal.pone.0080410)

84 Zhang S, Cardarelli K, Shim R, Ye J, Booker KL \& Rust G. Racial disparities in economic and clinical outcomes of pregnancy among Medicaid recipients. Maternal and Child Health Journal 201317 1518-1525. (doi:10.1007/s10995-012-1162-0)

85 Curtis EM, Moon RJ, Dennison EM \& Harvey NC. Prenatal calcium and vitamin D intake, and bone mass in later life. Current Osteoporosis Reports 201412 194-204. (doi:10.1007/s11914-014-0210-7)

86 Hossain N, Kanani FH, Ramzan S, Kausar R, Ayaz S, Khanani R \& Pal L. Obstetric and neonatal outcomes of maternal vitamin D supplementation: results of an open label randomized controlled trial of antenatal vitamin D supplementation in Pakistani women. Journal of Clinical Endocrinology and Metabolism 201499 2448-2455. (doi:10.1210/jc.2013-3491)

87 Yap C, Cheung NW, Gunton JE, Athayde N, Munns CF, Duke A \& McLean M. Vitamin D supplementation and the effects on glucose metabolism during pregnancy: a randomized controlled trial. Diabetes Care 201437 1837-1844. (doi:10.2337/dc14-0155)

88 Kalra P, Das V, Agarwal A, Kumar M, Ramesh V, Bhatia E, Gupta S, Singh S, Saxena P \& Bhatia V. Effect of vitamin D supplementation during pregnancy on neonatal mineral homeostasis and anthropometry of the newborn and infant. British Journal of Nutrition 2012 108 1052-1058. (doi:10.1017/S0007114511006246)

89 Marya RK, Rathee S \& Manrow M. Effect of calcium and vitamin D supplementation on toxaemia of pregnancy. Gynecologic and Obstetric Investigation 198724 38-42. (doi:10.1159/000298772)

90 NICE Clinical Guideline 63. Diabetes in Pregnancy. 2008. Available online: https://www.nice.org.uk/guidance/cg63

91 Soheilykhah S, Mojibian M, Moghadam MJ \& ShojaoddinyArdekani A. The effect of different doses of vitamin D supplementation on insulin resistance during pregnancy. Gynecological Endocrinology 201329 396-399. (doi:10.3109/09513590.2012.752456)

92 Asemi Z, Hashemi T, Karamali M, Samimi M \& Esmaillzadeh A. Effects of vitamin D supplementation on glucose metabolism, lipid concentrations, inflammation, and oxidative stress in gestational diabetes: a double-blind randomized controlled clinical trial. American Journal of Clinical Nutrition 201398 1425-1432. (doi:10.3945/ajcn.113.072785)

93 Innes AM, Seshia MM, Prasad C, Al Saif S, Friesen FR, Chudley AE, Reed M, Dilling LA, Haworth JC \& Greenberg CR. Congenital rickets caused by maternal vitamin D deficiency. Paediatrics \& Child Health 20027 455-458.

94 Anatoliotaki M, Tsilimigaki A, Tsekoura T, Schinaki A, Stefanaki S \& Nicolaidou P. Congenital rickets due to maternal vitamin D deficiency in a sunny island of Greece. Acta Paediatrica 200392 389-391. (doi:10.1111/j.1651-2227.2003.tb00563.x)

95 Orbak Z, Karacan M, Doneray H \& Karakelleoglu C. Congenital rickets presenting with hypocalcaemic seizures. West Indian Medical Journal 200756 364-367.

96 Marya RK, Rathee S, Lata V \& Mudgil S. Effects of vitamin D supplementation in pregnancy. Gynecologic and Obstetric Investigation 198112 155-161. (doi:10.1159/000299597)

97 Hashemipour S, Ziaee A, Javadi A, Movahed F, Elmizadeh K, Javadi EH $\&$ Lalooha F. Effect of treatment of vitamin D deficiency and insufficiency during pregnancy on fetal growth indices and maternal weight gain: a randomized clinical trial. European Journal of Obstetrics, Gynecology, and Reproductive Biology 2014172 15-19. (doi:10.1016/j. ejogrb.2013.10.010)
98 Ioannou C, Javaid MK, Mahon P, Yaqub MK, Harvey NC, Godfrey KM, Noble JA, Cooper C \& Papageorghiou AT. The effect of maternal vitamin D concentration on fetal bone. Journal of Clinical Endocrinology and Metabolism 201297 E2070-7. (doi:10.1210/jc.2012-2538)

99 Mahon P, Harvey N, Crozier S, Inskip H, Robinson S, Arden N, Swaminathan R, Cooper C, Godfrey K \& Group SWSS. Low maternal vitamin D status and fetal bone development: cohort study. Journal of Bone and Mineral Research 201025 14-19. (doi:10.1359/jbmr.090701)

100 Namgung R, Tsang RC, Lee C, Han DG, Ho ML \& Sierra RI. Low total body bone mineral content and high bone resorption in Korean winter-born versus summer-born newborn infants. Journal of Pediatrics 1998132 421-425. (doi:10.1016/S0022-3476(98)70013-7)

101 Namgung R \& Tsang RC. Factors affecting newborn bone mineral content: in utero effects on newborn bone mineralization. Proceedings of the Nutrition Society 200059 55-63. (doi:10.1017/S0029665100000070)

102 Weiler H, Fitzpatrick-Wong S, Veitch R, Kovacs H, Schellenberg J, McCloy U \& Yuen CK. Vitamin D deficiency and whole-body and femur bone mass relative to weight in healthy newborns. CMAJ: Canadian Medical Association Journal 2005172 757-761. (doi:10.1503/cmaj.1040508)

103 Viljakainen HT, Saarnio E, Hytinantti T, Miettinen M, Surcel H, Makitie O, Andersson S, Laitinen K \& Lamberg-Allardt C. Maternal vitamin $\mathrm{D}$ status determines bone variables in the newborn. Journal of Clinical Endocrinology and Metabolism 201095 1749-1757. (doi:10.1210/jc.2009-1391)

104 Viljakainen HT, Korhonen T, Hytinantti T, Laitinen EK, Andersson S, Makitie $\mathrm{O} \&$ Lamberg-Allardt C. Maternal vitamin D status affects bone growth in early childhood-a prospective cohort study. Osteoporosis International 201122 883-891. (doi:10.1007/s00198-010-1499-4)

105 Prentice A, Jarjou LM, Goldberg GR, Bennett J, Cole TJ \& Schoenmakers I. Maternal plasma 25-hydroxyvitamin D concentration and birthweight, growth and bone mineral accretion of Gambian infants. Acta Paediatrica 200998 1360-1362. (doi:10.1111/j. 1651-2227.2009.01352.x)

106 Sayers A \& Tobias JH. Estimated maternal ultraviolet B exposure levels in pregnancy influence skeletal development of the child. Journal of Clinical Endocrinology and Metabolism 200994 765-771. (doi:10.1210/ jc.2008-2146)

107 Lawlor DA, Wills AK, Fraser A, Sayers A, Fraser WD \& Tobias JH. Association of maternal vitamin D status during pregnancy with bone-mineral content in offspring: a prospective cohort study. Lancet 2013381 2176-2183. (doi:10.1016/S0140-6736(12)62203-X)

108 Harvey NC, Javaid MK, Inskip HM, Godfrey KM \& Cooper C. Maternal vitamin D status during pregnancy and bone-mineral content in offspring. Lancet 2013382 766. (doi:10.1016/S0140-6736(13)61827-9)

109 Zhu K, Whitehouse AJ, Hart P, Kusel M, Mountain J, Lye S, Pennell C \& Walsh JP. Maternal vitamin D status during pregnancy and bone mass in offspring at 20 years of age: a prospective cohort study. Journal of Bone and Mineral Research 201429 1088-1095. (doi:10.1002/jbmr.2138)

110 Congdon P, Horsman A, Kirby PA, Dibble J \& Bashir T. Mineral content of the forearms of babies born to Asian and white mothers. BMJ 1983286 1233-1235. (doi:10.1136/bmj.286.6373.1233)

111 Harvey NC, Javaid K, Bishop N, Kennedy S, Papageorghiou AT, Fraser R, Gandhi SV, Schoenmakers I, Prentice A \& Cooper C. MAVIDOS Maternal Vitamin D Osteoporosis Study: study protocol for a randomized controlled trial. The MAVIDOS Study Group. Trials 201213 13. (doi:10.1186/1745-6215-13-13)

112 Harvey NC \& Cooper C. Vitamin D: some perspective please. BMJ 2012 345 e4695. (doi:10.1136/bmj.e4695)

113 Azar M, Basu A, Jenkins AJ, Nankervis AJ, Hanssen KF, Scholz H, Henriksen T, Garg SK, Hammad SM, Scardo JA et al. Serum carotenoids and fat-soluble vitamins in women with type 1 diabetes and preeclampsia: a longitudinal study. Diabetes Care 201134 1258-1264. (doi:10.2337/dc10-2145)

114 Baker AM, Haeri S, Camargo CA Jr, Espinola JA \& Stuebe AM. A nested case-control study of midgestation vitamin D deficiency and risk of 
severe preeclampsia. Journal of Clinical Endocrinology and Metabolism 201095 5105-5109.

115 Makgoba M, Nelson SM, Savvidou M, Messow CM, Nicolaides K \& Sattar N. First-trimester circulating 25-hydroxyvitamin D levels and development of gestational diabetes mellitus. Diabetes Care 201134 1091-1093.

116 Soheilykhah S, Mojibian M, Rashidi M, Rahimi-Saghand S \& Jafari F. Maternal vitamin D status in gestational diabetes mellitus. Nutrition in Clinical Practice 201025 524-527. (doi:10.1177/0884533610379851)

117 Zhang C, Qiu C, Hu FB, David RM, van Dam RM, Bralley A \& Williams MA. Maternal plasma 25-hydroxyvitamin D concentrations and the risk for gestational diabetes mellitus. PLoS One 20083 e3753. (doi:10.1371/journal.pone.0003753)
118 Parlea L, Bromberg IL, Feig DS, Vieth R, Merman E \& Lipscombe LL. Association between serum 25-hydroxyvitamin D in early pregnancy and risk of gestational diabetes mellitus. Diabetes Medicine 201229 e25-e32. (doi:10.1111/j.1464-5491.2011.03550.x)

119 Savvidou MD, Akolekar R, Samaha RB, Masconi AP \& Nicolaides KH. Maternal serum 25-hydroxyvitamin D levels at $11^{+0}-13^{+6}$ weeks in pregnant women with diabetes mellitus and in those with macrosomic neonates. BJOG: An International Journal of Obstetrics \& Gynaecology 2011118 951-955. (doi:10.1111/j.1471-0528.2011. 02982.x)

120 Marya RK, Rathee S, Dua V \& Sangwan K. Effect of vitamin D supplementation during pregnancy on foetal growth. Indian Journal of Medical Research $1988 \mathbf{8 8}$ 488-492.

Received 1 October 2014

Revised version received 10 March 2015

Accepted 10 April 2015 